計と論らあめし深小の用は不わ

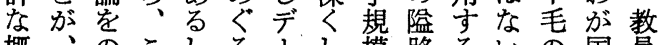
概、のこしる1:し模路るいの国員 念本べの、役夕てののによ原で役 で稿て調そ割もいいよはう因は割 あの、查の期もる役う、では、の る意教にう待ち。割でま市年こ か図員ともとあこ期あだる教のと

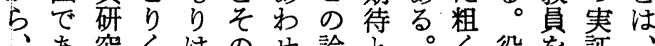

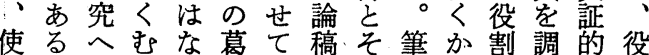
亏。の過い藤いのの者つ理查研割 の役役程。のな筆葛注整論の究理 は割割でっ、索、理の対は論 止と理遭た実筆執の小分諸象皆で めい論遇な状者る調学よ概と無よ たうかしい二江查校く念すとく ほ概らた調般はあを教ではるい引 弓念の疑查を、た実員き、こっ合 加注了問の論わっ施にて実とてい よ、プと結ずがてし関い証のよに い矛口它果る国もてしな操むい出 盾、れのこの、みてい作つでさ とを報と今理てここのかれ

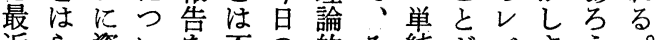

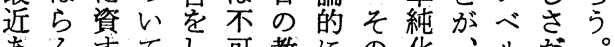
あ冗夺てし可教にの化、ルだ。し るだるのな能員低感し根でけこか 論余こ試がでを迷をた本使でのし

教

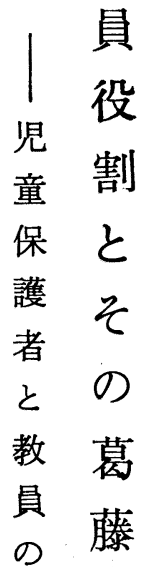

場

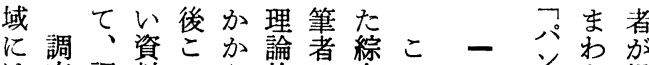

注查調料の元的注合の提

他対查で種てな、的教㶲今れ唱 町象のあのきゆ調な員 に地概る調たき查孝役 も域要必查。詰方咅割 をとを要注今法調の たな報すお百のに查調 がっ告なこにた若 るた导いななめ年注 大 $\mathrm{H}$ るのわっ、のの き町。で炛調尔黄擗

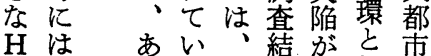
団五たなす笨あ调

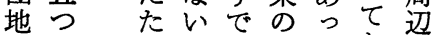
がのめしに発たお地 で小て、古表ここ域

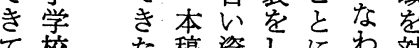
て校た稿資しにわ対 い芳資の料な気れ象 たあ料意でい付たに

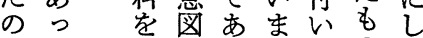
でた。再かるまたすて あこ整点架資と京䨈 尔地理新々料々る。学

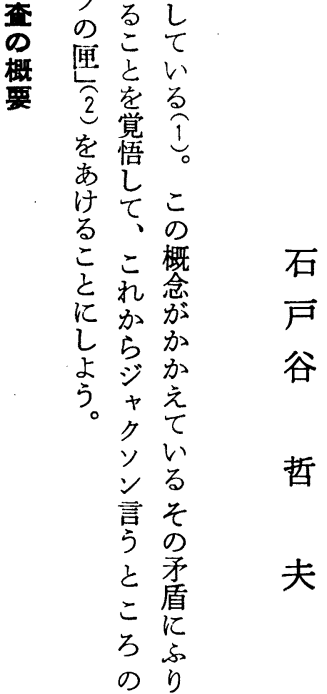


図 1 教員群・保護者群における教員に関する役割期待の比較

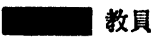

$\square$ 保讙者

\begin{tabular}{|c|c|c|}
\hline 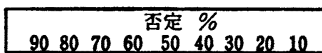 & 役 割 項 & 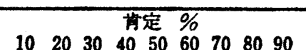 \\
\hline & 1.しつけのため時には体固もやる & \\
\hline \# & 2.宿题を出す & \\
\hline & 3.親の熟心さで岏童指導が影警される & \\
\hline & 4.勤杵時間たけけで代事を切あげる & \\
\hline & 5.受持っている児童の家庭教師をやる & \\
\hline & 6.女教具か職場では服装なと地味に心がける & \\
\hline & 7.女教具か外出時に服装なと地味に心がける & \\
\hline & 8.学校をよくするために政治運動をやる & \\
\hline & 9.教育の内容・方法まで文部省にしたがう & \\
\hline & 10.教貝組合に加入する & \\
\hline & 11.組合本部の指令にかならずしたがう & \\
\hline & 12.組合の言い分を通すため授業放黄する & \\
\hline & 13.体面上，交峦する人をえらふ心 & \\
\hline & 14.デモに加わる & \\
\hline & 15.一般の人がデモに加わる & \\
\hline & 16.パチンコ屋で遊ぶ & \\
\hline & 17.一般の人がパチンコ屋で遊ぶ & \\
\hline
\end{tabular}

肯定または否定か50\%以上のものたけを棒クラフで示してある。

*印は，否定肯定とも50\%に達していないことを示す。

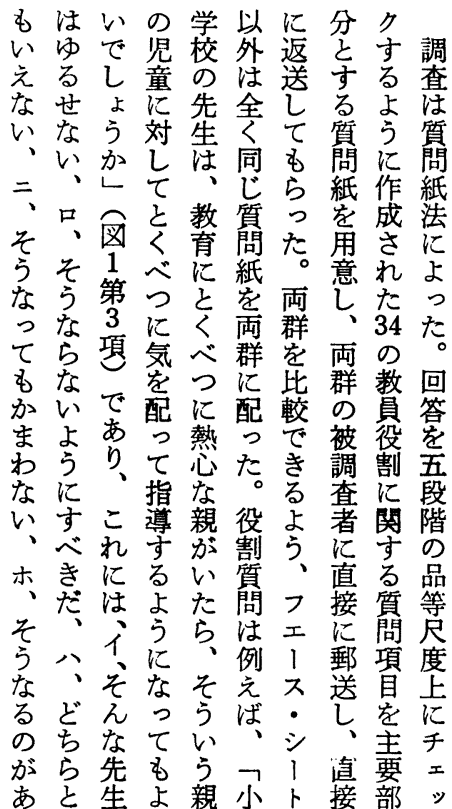

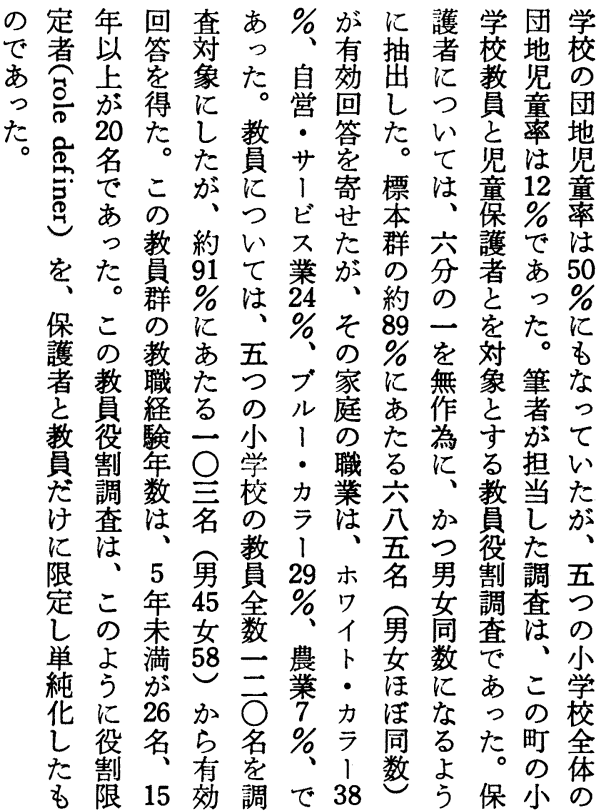




\section{教員役割とその葛藤}

表 1 役割期待のまとまりの比較

\begin{tabular}{|c|c|c|c|c|c|c|c|c|}
\hline 役割 & \multicolumn{2}{|c|}{ 平 均 点 } & \multicolumn{3}{|c|}{$\sigma^{2}$} & \multicolumn{3}{|c|}{ 支配的傾向の\% } \\
\cline { 2 - 9 } 項目 & 教員 & 保護者 & 教員 & 保護者 & $*$ & 教員 & 保護者 & $* *$ \\
\hline 1 & 4.22 & 3.67 & 0.66 & 1.43 & + & 88.3 & 67.4 & + \\
2 & 3.19 & 2.18 & 0.89 & 0.73 & - & $\times$ & 80.3 & - \\
3 & 2.02 & 1.82 & 0.64 & 0.55 & - & 89.3 & 90.7 & - \\
4 & 2.98 & 2.62 & 1.34 & 0.94 & - & 50.5 & 61.1 & - \\
5 & 4.59 & 3.97 & 0.47 & 1.01 & + & 95.1 & 78.2 & + \\
6 & 3.53 & 2.32 & 1.18 & 1.01 & - & 63.1 & 70.3 & - \\
7 & 4.21 & 3.21 & 0.54 & 1.09 & + & 93.2 & 55.1 & + \\
8 & 2.53 & 3.25 & 1.22 & 1.43 & + & 56.3 & 51.5 & + \\
9 & 3.61 & 2.65 & 1.01 & 1.03 & + & 62.1 & 57.5 & + \\
10 & 4.08 & 2.89 & 0.85 & 1.21 & + & 79.6 & $\times$ & + \\
11 & 2.57 & 3.27 & 0.85 & 0.80 & - & 58.3 & 52.2 & + \\
12 & 2.42 & 3.36 & 0.71 & 1.14 & + & 71.8 & 61.3 & + \\
13 & 4.05 & 3.48 & 0.44 & 0.97 & + & 86.4 & 62.2 & + \\
14 & 1.79 & 3.22 & 0.83 & 1.58 & + & 87.4 & 51.0 & + \\
15 & 4.05 & 2.71 & 1.42 & 1.66 & + & 70.9 & 55.1 & + \\
\hline
\end{tabular}

* +のサインは教員群のほうが分散度が低いことを 示す。

**＋のサインは教員群のほうが支配的傾向の支持率 が高いことを示す。

ちか員相

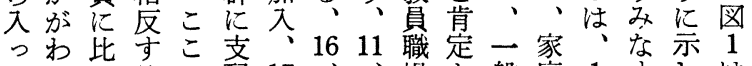

$$
\text { 群加る う、整と } 15 \text { ， } 5 \text { 、の う う }
$$

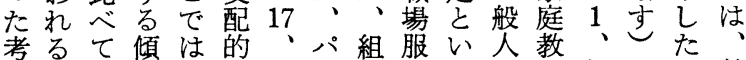
察こ禁向、傾一チ合装うの師体がも教 法々止が管向般ソ指よデ、罰両の貝 後を的め理が人コ令 8 , $气$ モ 7 群で群 に指拘だ者なの遊、、にで、3忞あと ま摘束つにいパび 12 政反あ女向る同る保 わす 的こ対 するでとす こにあ、る ととる保あ にどこ護り すめと者方 る、がの の 。役、役 領 た割図割域 だ葛 1 期で 乙藤か待両 、ら注群 役たう教の
チで、治対り、贅熱じ支護 コる業動な両外影否配群 遊。放、口群出響定的の

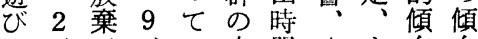
に、、、い支服 4 女向向 ぞ題デ部の的勤は 50 比 ぞ 10 モ゙省が傾 13 務肯\%俥 ら、にし 6 㤎体あで上き か組加た、㫘面げあるる は宿 14 文る配装、たっ学
の児るはしらた あ童わ肯たれり り宁定者てま 方指で卞 に導ある否るだ 関にるよ定。 寸関。うす教の るす教なる員品 もる員規よの等 のもの準うそ尺 6 の あ的なの度 、7 万期規よ方 管、方基準うつ 理児にを的ない 者童関も期行て にの娄っ待動い 対親るてをにて すとそい、関 るののる あ関 34 は、て答 り係項ずホ、者 方に自だイの

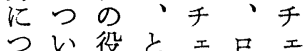
いて役と割想ッに て 5 筫定クチク $6 、$ 問ししェが 、勤注てたッ求 地務、い者クめ

なのあ考のあ域

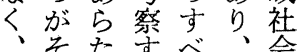
参れめるて他で 考でて材ににの 質あ番料わ参行 問る号とた考動 でがゔしつ算に あ、けてて問つ る第を適報 4 い 15 当告がて 、てだ卞加 6 17 扱文るわ 項っ思こっ教 はてわとて員 教ゆれはいと 員くる必る。 あとので本の りに項な稿属 方す自いで性 にるだかはに 関。汀 ら。閔 寸図老、こ籿 る 1 役和る 質にき割らも 問示だ葛 34 の でしし藤項 4 はた、を自で 


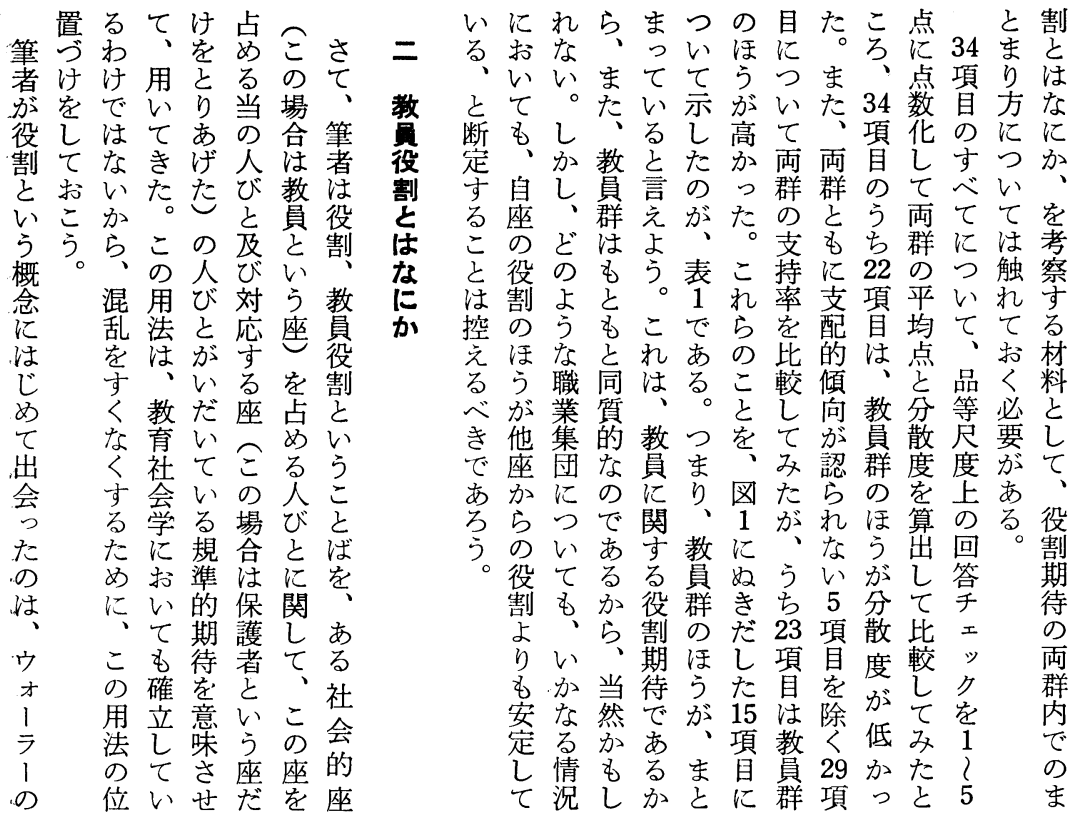

動特るよは後でのとる化ナ、行割ばうきがまと人し書 教の定究び場こあは解具さり、動だ、る、個なものいの

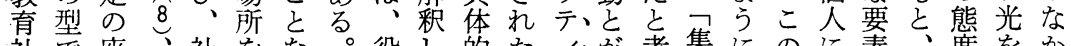
社で座、社をな。役し的た仿考集にのに素、度をか 会あをと会占る一割た社役も生完団個惹が社を放で 学る占しのめ説ににも会割意ず生個人きひ会反っあ

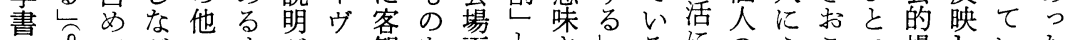

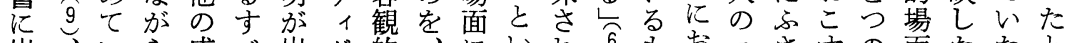

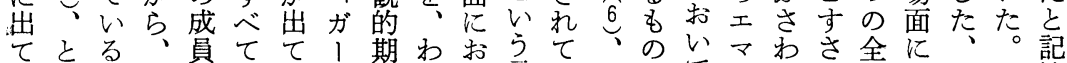

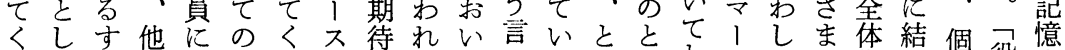

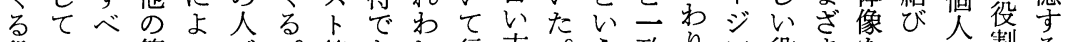
役いて筒っび。等なれ行方。う致りシ役まをつの割る

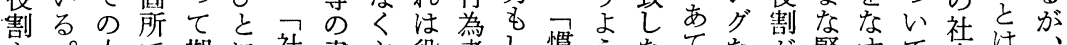

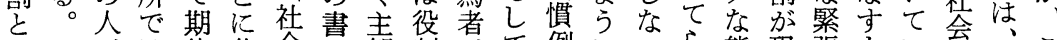
いびは待共会で観割が、例にいら態現張もい䉿宓

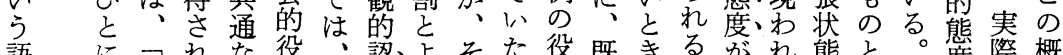
語に杂な役、認よそた役既きるがれ態と。怎際概

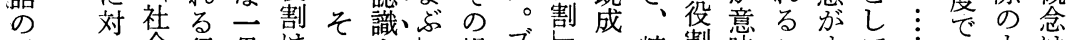

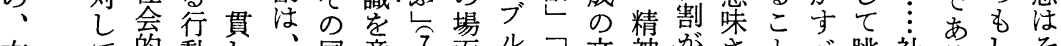

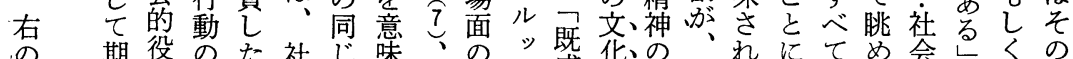

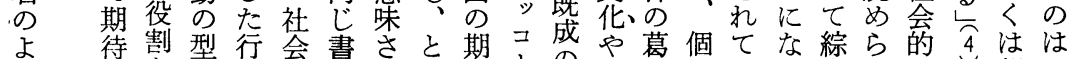

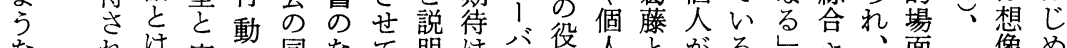

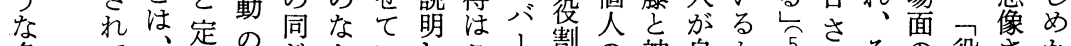

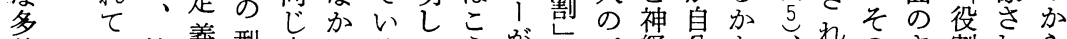

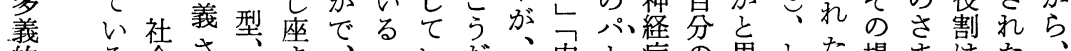

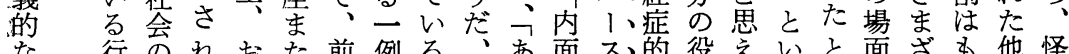
な行市れおた前例る市面ス的役えいと面ざす他怪 


\section{教員役割とその葛藤}

がさ゚て の言こけに割群のすも

によいい不加えのる勤項の程べのと

ミてな思。る程べめ目教度きでこ 別 いい議 40 の度きる第筫のたるら に吉る。な\%でなで同7役人、るで

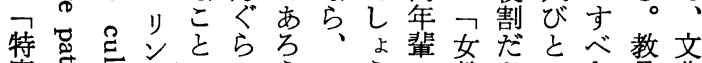
定芦卜にいうこうの教とにき贅炛 のヨ利 場。が従ら。こし性た党っな座と 面导加来、支とに方るていを注

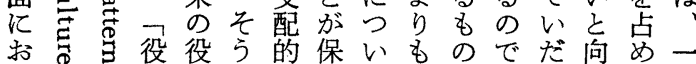

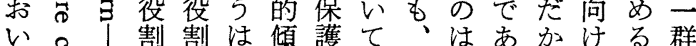
て。論言向者、服、万れら者の い吉筆い者えが群保装学うてれに人 から者う泩な50の護や校かいる関び に它註こ、い\% 教者化に。る規しと 行总之ここのぐ員の粧勤例と準てに 動品りばのから役70をめえき的、共 卞 ン は疑。い割\%地るばに期教有 ベにト、問でにが味と、、待員さ き分ン特にもな肯にき筆そがたれ かけは定ま にて 文市 つ論化座を いた型結答 てほをびえ

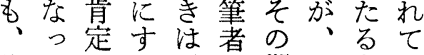
そてしる、の期あもい ういてょ会調待るのる 言るいう社查が群は注 え、る心なのそのかず ると。唯ど役のどくの
るい分割個ので用 っけ人さ法 てた (3)がまる。 い合社自ざ。 る。会他ま教実 そこ的のな䏍は のこ座社用長社 役の兴法役会 割分占的を割科 と年め座整調学 は方てを理查に 、にい考しをお (1) しる慮ておけ のた当し、こる 規がのて (1) 役 準え行場規っ割 的ば為面準たと 文、者を的グい 化筆 の限文口ら 型者行定化 $ᄌ$ 概 と が動し 型等念 し本とたとはの て稿し\&し、混 のでてのて 役乱 役教のとの割の 割貝役し役と反 で役割て 割い映 あとに役 (2) 語の

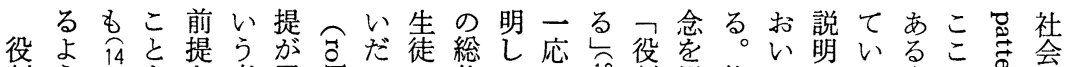

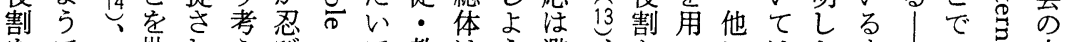

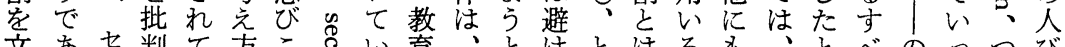

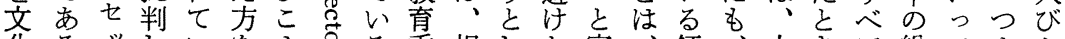

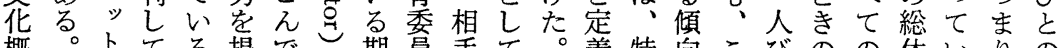
概。卜七る提でし期員手て。義特向こびのの体いりの 念内役の出いつ待なの座しし定がのと、人をる規竟 と の割でしるまかど座のかてのあょのとび意文準竟

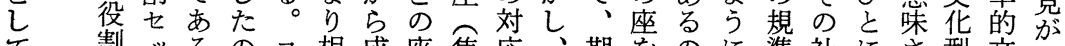
て 割ッるのコ相成座焦応、期をのに準社にさ型文— 用部 $ト$ に手っ点関座街占にコの会対せを化致

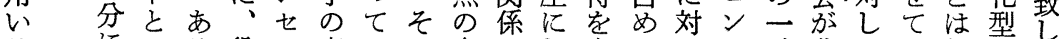
るにいる役ン座い杂座の方向るして致曲て用規とて 限つう座割サごるぞがモすけ者てンへ者心い準いい りて用の部スと、れ教デびるに、サるでるる的うる

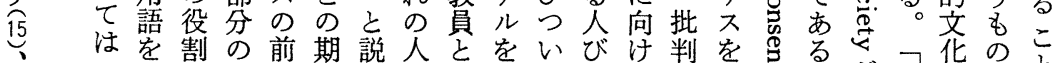

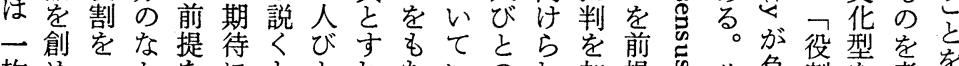

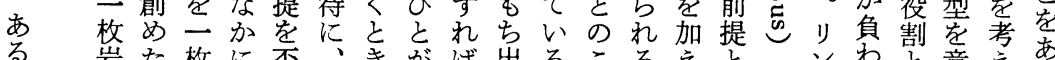

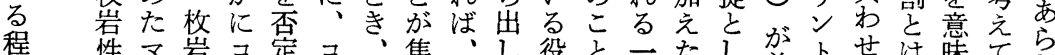

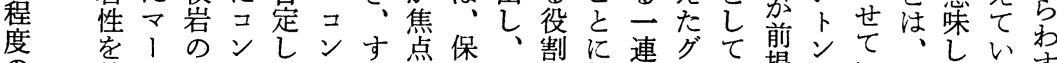
の 前トよセてセでの護あを触の口連提のいそてたす 致提 ンうン役ンに座者る其れ期不割と役るすいの

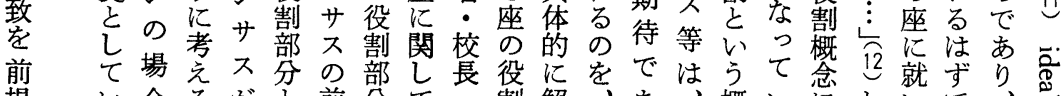
提 い合るがと前分て・割解、あ、概いにといで 


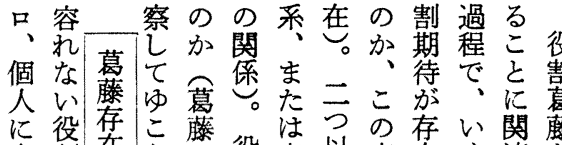

に役存こ藤役座以事在く連躇 識期論。様割意実守つしい さ待—相期まのにるかてう れ茫役梠た相面との用こ た存割 そ在論 のす者

よるが

うと役

ない割

事う葛

実客藤

を観に

意的 つ

味事 以

さ央て

せを語

た意る

り、昧之

さき

、せ 、

人、相考な脽体存る役るあ

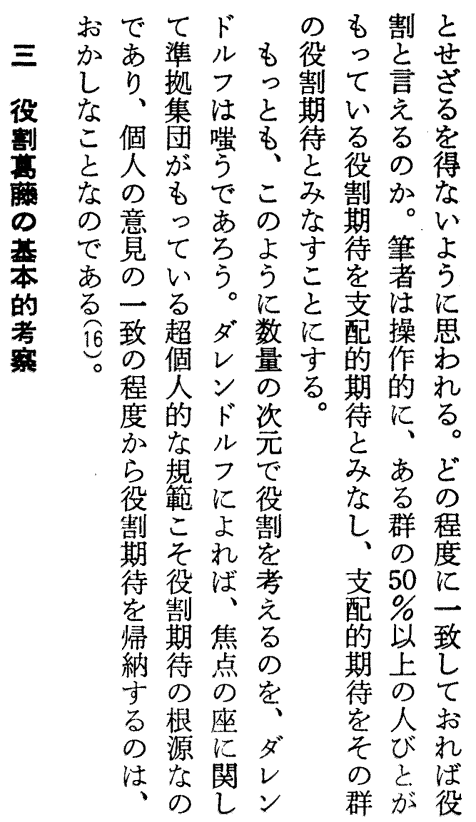

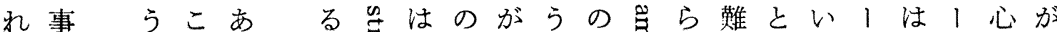

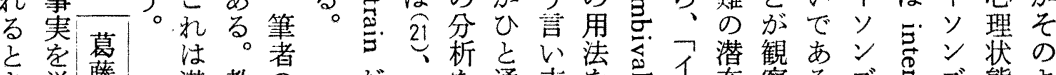

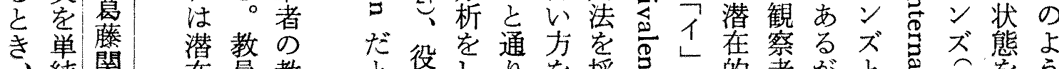

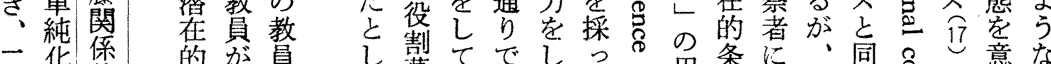
二化係 的分員 亏し論暮実役 のて藤際 割 期、相雀に調 待二容分経 查 のう机析験に 位のぬに卞打 置役二するけ 関割亏ぎ役る 係期以な割葛 は待上 $上$ 緊 藤 さとの、張 分 まし役之老析 ざよ割い問の ま う期 う題葛 に。等こと藤 考役方主守注 え割存にる ら葛在な立イ れ藤守る場し てがるな゙かの お論と でら意 りせい市洙 て暮てでしつ用条に、同る意な て藤いなててと法件よ役様虫は味事

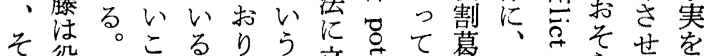
の役教とる。方語立导認䓪個とらな意

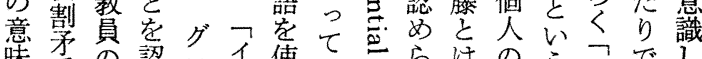

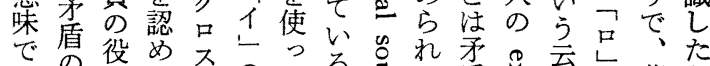
の゙の結割た等のてる意のた矛采云し葛り

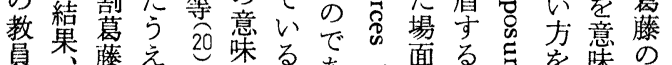

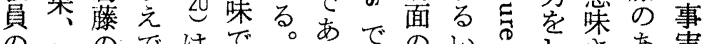
の個のではで。あでのいのしさあ奏

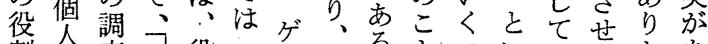

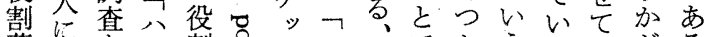

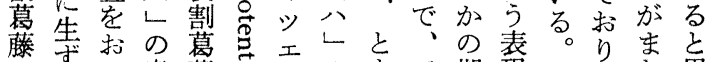

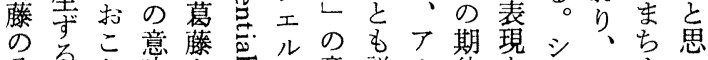

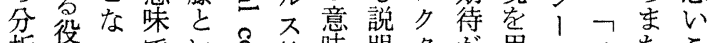
析割つでいす等味明名架用、公台こ

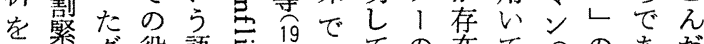

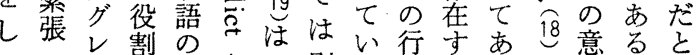

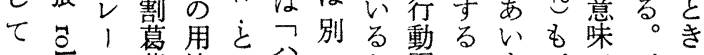

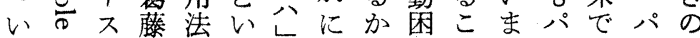


てょ卜に外ら的をへ型迷しる-とめ会究とし能も論

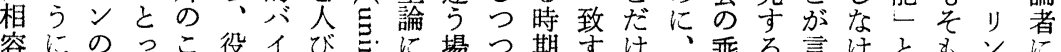

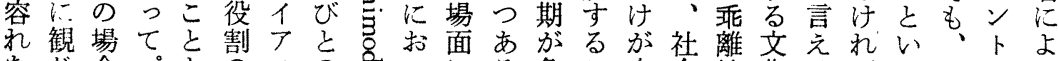
な心合プとのスの包いにる急こ支会性花るばっ社ンっ いたラ見整と一てし。速と持全を人。な社にて

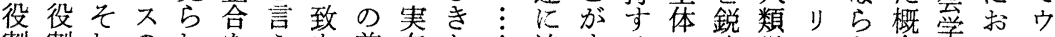
割割れのれをえを前在り 期葛はもた説な前提齐飞個っく周人指者卜いに文るイ

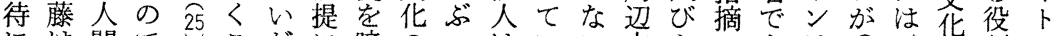

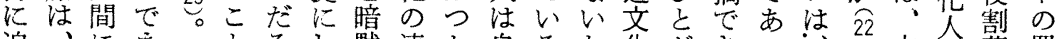

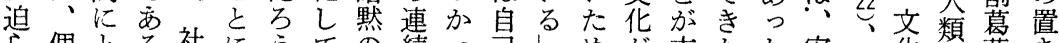

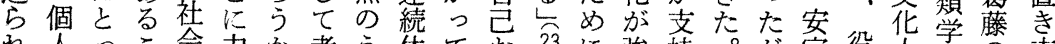

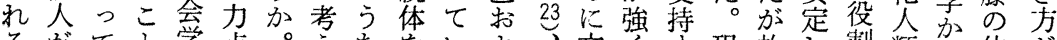
るがてと学点。光古いょ文く寸現故し制類ら位㕸 とこのを者忐こたに説るびつ化なる代にたと学々置こ

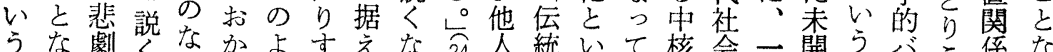

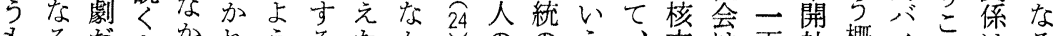

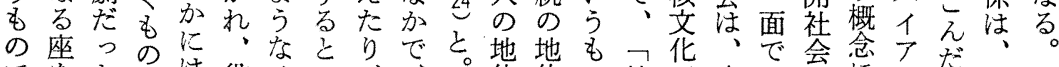

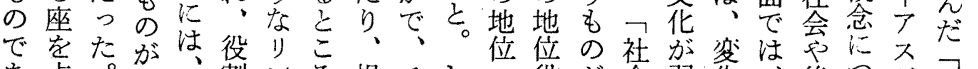

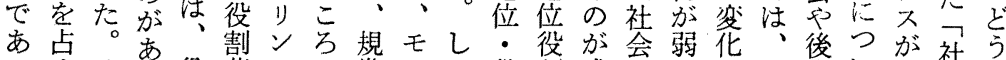

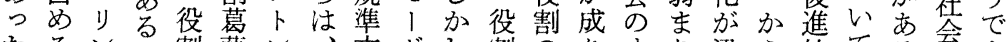
たるンが割藤ン、文ドし割のりすり逮え社てる会あ

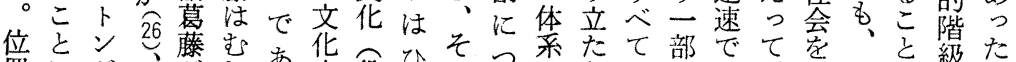

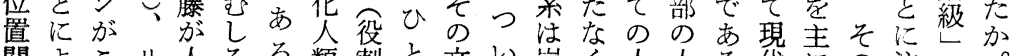
関よこリ人ろる類割と文い崩く人人る代にの注。 係っのン間例か学しっ化て壞ながびた社研こ意機そ

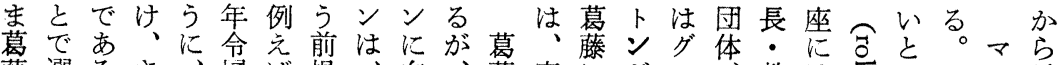

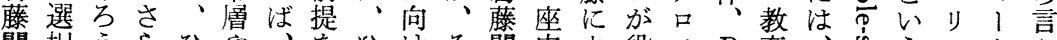

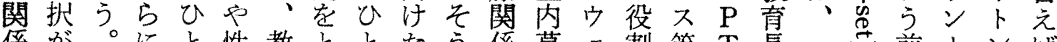

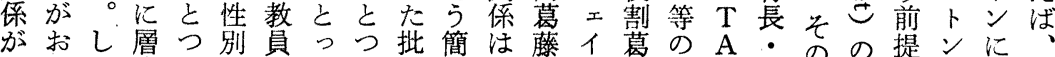

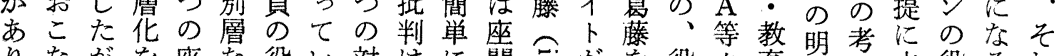

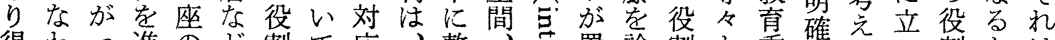
得わっ進のど割て底、整座置諭割々委な碓方咅割とは

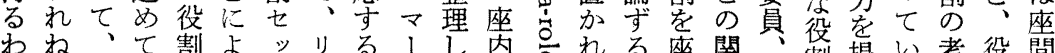

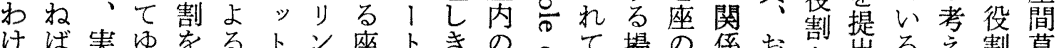
けば赛ゆをるトン座トきのって場の係打嵒るえ割葛

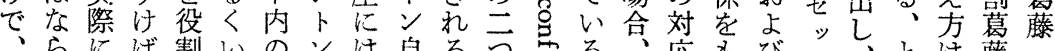

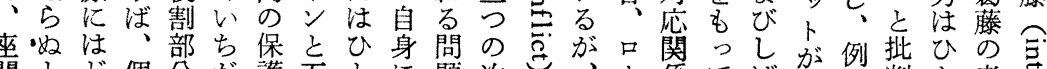

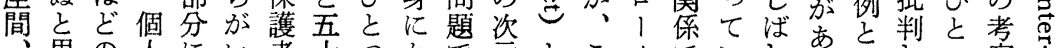

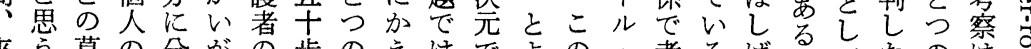

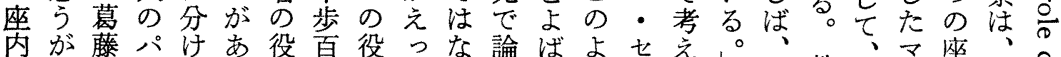

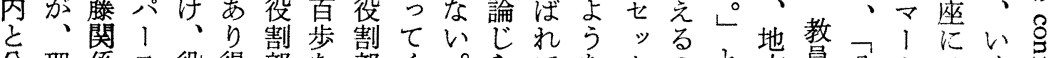

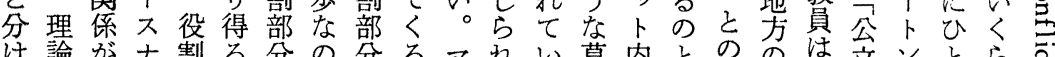

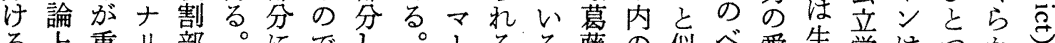

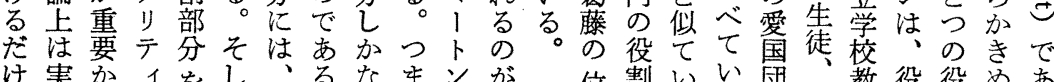
け実か、をし、るなンが位割いい田教役役め

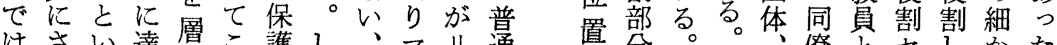

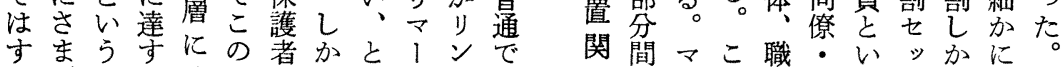

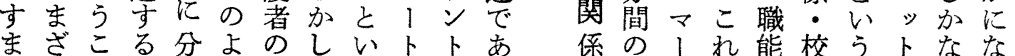


向の䓃は方保い言 るだ部も。間葛目みか不互考な で有ら、向護うい葛こ分とこ葛藤間のっ等にえさい 無吕両に者様方葛とそ全ゔの藤と葛生て等るらう 程をの群な群相は藤にれ体いよをい藤活、役盾論にで

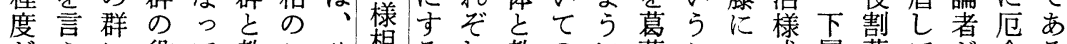

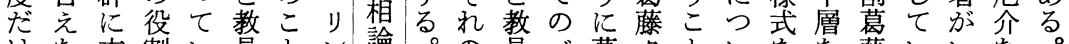
けな支割い筫とン論。の筫べ葛多といをな藤いいな がい配期る群な卜—部部る藤イにてて維みのるる。 ちの的待第ののン相分分葛関プもの持の研こ。之 がで傾が 6 支か以容の全藤係のつも給究とひに つ向葛: 配。来机層体分はひぱのる料はをとは てろ方藤 8 的筆使な いうなし・傾者わ以 るかいて 9 向のれ 第。第い:各調て吉 1 両 2 る, 11 、查々。

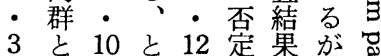

3 と 10 と 12 定果が、总

4 に 17 完 14 肯つ相寄

・否項る・定い容

5 定にの 16 とて 役

- かつでのいいな割

7 肯いあ項 うえい期

・定てろ自よばと待

13 かはうにう情

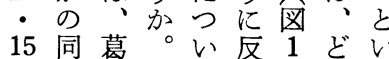
項方藤どて対

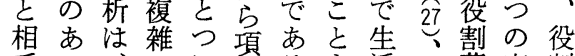
手い、でに貝るも活、葛座割 のだ教あ挙間。期守コ藤の葛 部、員るげ葛教待るミと役藤 分そ役がる藤㕕しこニよ割と 全れ割、29 社てと三ぶ期い 体ぞの次意会いをテこ待う のれ同節ひ燊学る期ィとのこ あの二でどさ者、待のもなと い部項筆がせのとし人あが だ分自者いたないなる゙るる。全

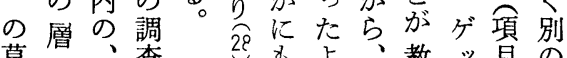

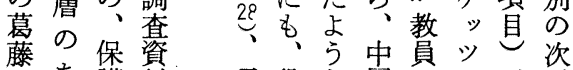
にあ護料項役な層に賁にが垐 限い者に自割項な向ル相で

葛しのり葛お究グしびあにがうし育だてつ教ああの

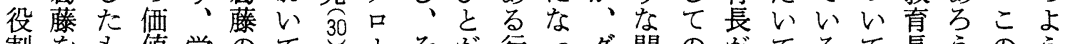
割をも值学のて田、ぞ行っグ問のがてるて長うのう 葛分の観校研もにブのぞ動てロ題役思い。個か問な 藤析でと組究採お等回え項いスも割っるそ項々。題場 のし、合織はらいの答な目る等生期て役の目人グを合

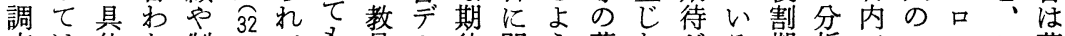
查は体な制它て員1待関う葛ながる期析で心不こ葛 のい的い度教いの名しで藤か扱も待のの理等れ藤 先なな、の教るプ役を奇てあ分っわので役、理のまし 例い役こ前員。ラ割もせ役る析たれをな割座レ教でて は。割とでとこイ葛とて割。ののな呈くデ内べ市のい 、期な脆しれ不藤にいせ暮しでか䒬、1役儿長実る 右待どくてら等葛るッ藤かあっさ相夕割に役証と ののか、のとの教藤と、トのたりたせ手は部置割的は よデら立役は警員を思内存が、のたの、分きの研言 う 1 生身割別察役論つ、の在、参でデ座相間き葛究光

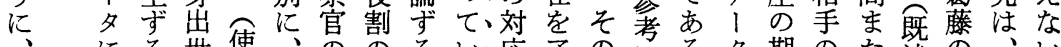

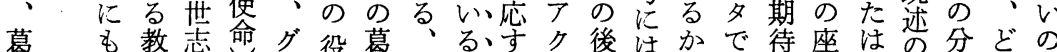

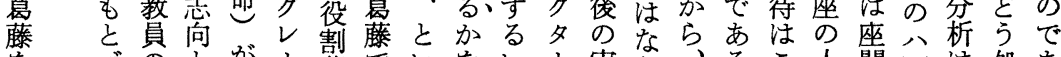

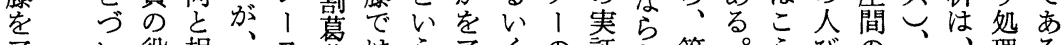

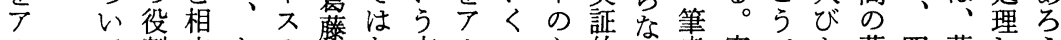
クて割容あの年な方クつ主的い者客でと葛四葛しう タそ緊衍教研い法タか観研。に観あ吕藤つ藤てか

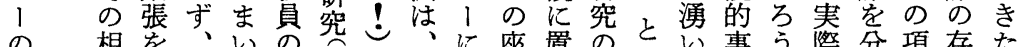

心 相考世で役 31 に察間あ割に研ス問人、本ろよを教いしにをで 


\section{教員役割とその葛藤}

るのの答とうの教亦期役が役こ容が対かうだいお

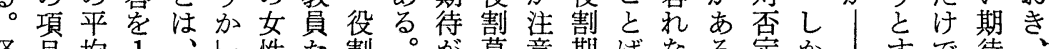

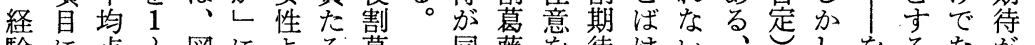
験に点々図による葛同藤を待はいてをなが実 15 関と 51 関りを藤一惹落矛関とと、解筆く存際 年才、点にしものに定い存盾係し強グく者役在の 以る両に示て、注行義た在守をてさ口参の割守役 上役群点し、服、強動寺。专る、いのス考問部る割 の割の数た教装学弱項るこる役矛る相等に題分と期

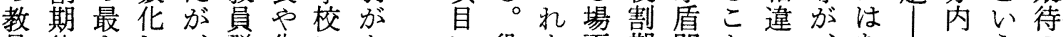

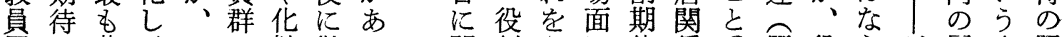
層の若、五と粧勤る関割参は待係 33 同役らど層事照 と連い教段保をめ。葛考役㤎と方割なの間実合 35 続層員階護地る筆て藤に割存反向期いよにをを 歳体と群の者味と者相とし湆在対まで待。うま役お 末 箖お品群にきの 満上もよ等のすは調 のに年び尺役る、查 若位輩保度割よ会で: い置の護上期う社: 保亏゙層者に待心な役 護けと群チががど割 者たのそェ葛けに項 盧の平れッ藤る勤自 とが均ぞクしべめ第 の図点れさてきる6 あ 2 をのれいで同項 いであこ全たるし回こょ輩女 反はてレ方関たのの 娄、、当係、程相文暮な るあ筆、場にプ度違い艺藤っ 方る者と面区ラのに方入とて 向二法に别イち注占っしい をつ次え対し不が、いていな とののでし、等い方を葛座い っ坐よいて役为し向暮藤内の てにうる用割役のの 藤のので い関にこい葛割二相と様役 るす操と、藤期つ違还相割相 こる作危反と待のっ ぶを部容 之役的 34 対いの次肯べみ分れ だあこ体回こょ輩女で割に、のう相元定きよ間な

とていの葛との夫らよ な 次の役 りにで割 得 は る、検 役 筆 討 割 う者を葛 なの加藤 こ役えと

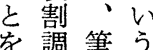
を調筆 う ひのな念 きデりは 出 1 の し夕操ず て 作 L み 5 的 8 よ、限す 教定 2 員をき 役提 り 割 出 L のした 葛宁舟 藤きの のたで 仮。は

四架藤で相がよう。 。を子違つい

教役りよ注かのし 割もぶ、なかか 葛問ききい。平令 に題むの均葛 つがの筆た点藤 いあだ者、のの てりがの経ひ強 のそ、定験らさ 筆引若義 15 き 者でいに年で客 のあ保よ以言観 操る護れ上っ的 作。者ばのてに 的役看葛教よ述 限割と藤員い心゙ 定の年で層のる はず輩はとか根 れ教な 5 、拠 摇を員く年筆省

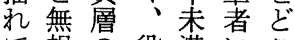

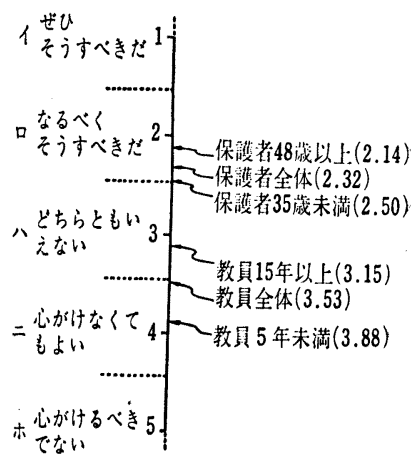

て視の役満にここい比層年 48 い年くわの いしあ割のはにと、較の輩歳教末、め葛 るていの教ま置孞と的暮保以貝満経藤

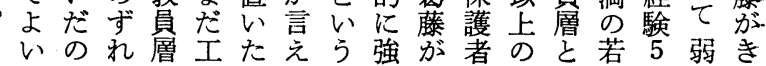

図 2 役割葛藤の様相の例

第 6 項 女教員の職場での服装 地味に心がけるべきだ 
図 3 教員群と保護者群の役割期待分布 の比較

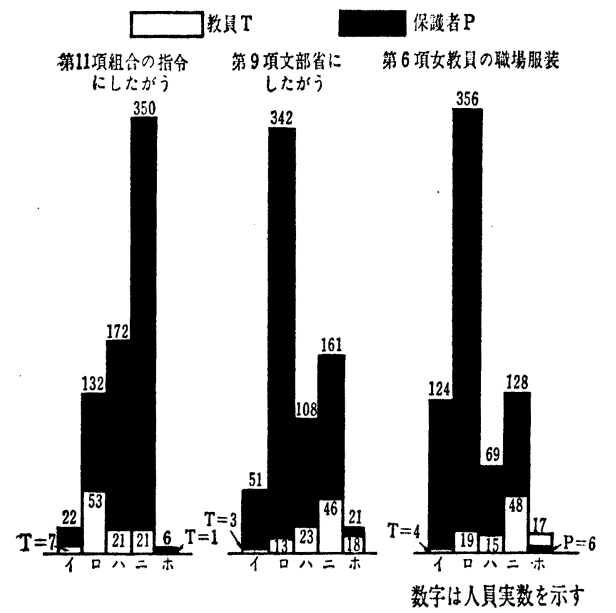

項業 2.7 の服队 34 割 ろて 分放、政装きの期も否 1 于畺第治出引待五定

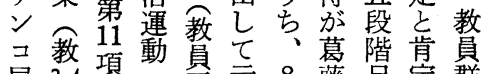
屋 2.4 項是平 8 脽等定群

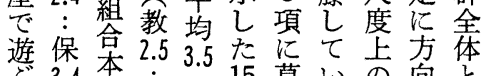

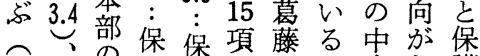
教等指 3.3 護算等主点为護 4.1 第会 者の成及老古者

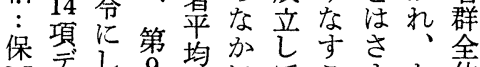

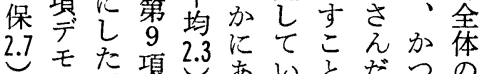

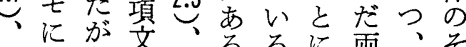
で加う部第る。比禹乘れ

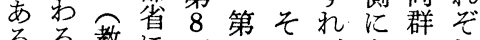
るる教に項 6 のば每のれ 因教 2.8 学項亏方平以 11.8 保た校女古設場均支 の： 3.3 势教の定合点配

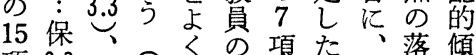
項 3.2 第教守職檪役両落傾 の、123.6 る場図割群る唯 う第項: たで 1 項のとあ 、16授保めのに目役こっ

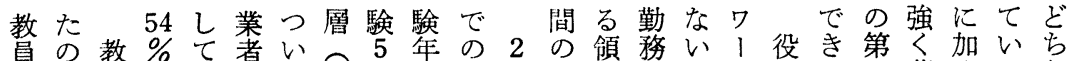

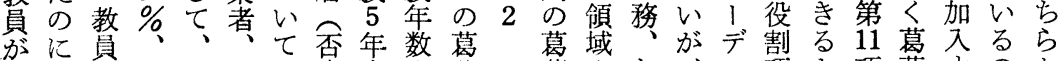
役、群平 48 には定末別藤ぬ藤やな、ィ項よ項藤すのか

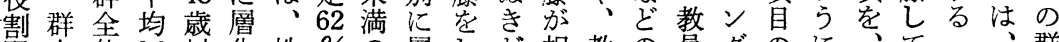
緊内体 2.9 以化性\%の層しだ相教の員グのにてて群 張部と 上し別平教华 5 対筫領役の設示例い教第に をの保ののて平員しべた的不域割適定しと严 4.12 支 実層護あ層層年均層たて 15 にテなの不のたし第: 項配

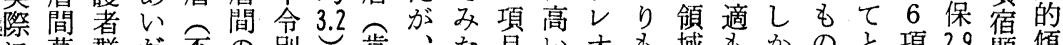

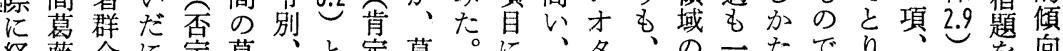
経藤全に定葛定葛。に、タ、の的たでり、向 験注体葛 57 藤学の 50 滕教つとイ管引様にああ弱でだが

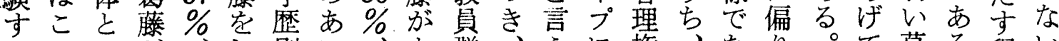

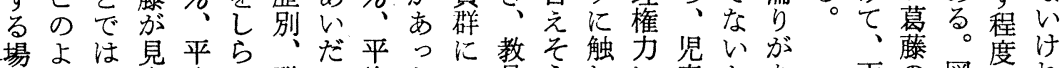
合う、出均べ職に均たつ員うれに童かあ にに 15 さ 3.4 た業だ 3.2 のい群でる対のらる

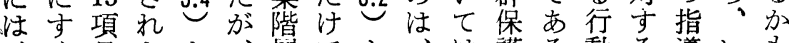
く自たと、層でと、は護る動る導いる 教なのだ 35 わ別あ経第、者。領教古し

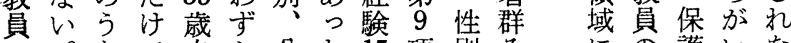
の。ちで米か公た15 項別そにの護いな あし7 あ満に団。年に机自者にい いた項る。第居保以関学ぞ だがで。層 14 住護上し歴れ

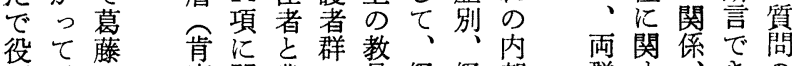
割、定関農に員経経部群夺保きの 両㫌図度れ 群第 3 教 ど の 9 は 3.2 \& 役 項、 割穴こ保均 期きれ 2.2 点 基わら洨 のめの 反 以主亡注し分七う第詨 て性の断、布弱方 10 側 艺比項に 比葛較組落 較藤的合 ち 
教員役割とその葛藤

表 2 保護群に対する経験年数別教員 蟹の役割期待の距離の比較

\begin{tabular}{|c|c|c|c|c|}
\hline \multirow{2}{*}{$\begin{array}{l}\text { 役 } \\
\text { 割 } \\
\text { 項 } \\
\text { 目 }\end{array}$} & \multicolumn{2}{|r|}{ 均 } & 点 & \multirow{2}{*}{$\begin{array}{l}\text { サ } \\
\text { イ } \\
\text { ン }\end{array}$} \\
\hline & $\begin{array}{l}\text { 経験15年 } \\
\text { 以の教 } \\
\text { 員20人 }\end{array}$ & $\begin{array}{l}\text { 経験 } 5 \text { 年 } \\
\text { 未満の教 } \\
\text { 員 } 26 \text { 人. }\end{array}$ & 保護者群 & \\
\hline 6 & 3.2 & 3.9 & 2.3 & + \\
\hline 8 & 3.2 & 2.2 & 3.3 & + \\
\hline 10 & 3.6 & 4.5 & 2.9 & + \\
\hline 12 & 2.8 & 2.4 & 3.4 & + \\
\hline 14 & 2.6 & 1.5 & 3.2 & + \\
\hline 16 & 3.7 & 4.1 & 2.7 & + \\
\hline
\end{tabular}

注十のサイン注、経験15年以上の教

員層のほうが保護者群に接近してい ることを示す。

表 3 教員群に対する保護者の年齢別・ 公農別層の役割期待の距離の比較

\begin{tabular}{|c|c|c|c|c|}
\hline \multirow{2}{*}{$\begin{array}{l}\text { 役 } \\
\text { 割 } \\
\text { 項 } \\
\text { 目 }\end{array}$} & 平 & 均 & 点 & \multirow{2}{*}{$\begin{array}{l}\text { サ } \\
\text { イ } \\
\text { V } \\
*\end{array}$} \\
\hline & $\begin{array}{l}\text { 48歳以上 } \\
\text { の保護者 } \\
102 \text { 人 }\end{array}$ & $\begin{array}{c}\text { 35歳末満 } \\
\text { の保護者 } \\
129 人\end{array}$ & 教 員 群 & \\
\hline 1 & 3.5 & 3.8 & 4.2 & + \\
\hline 3 & 1.8 & 1.7 & 2.0 & - \\
\hline 7 & 3.3 & 3.8 & 4.2 & + \\
\hline 10 & 2.7 & 3.1 & 4.1 & + \\
\hline 13 & 3.2 & 3.7 & 4.1 & + \\
\hline \multirow[t]{2}{*}{14} & 3.8 & 2.9 & 1.8 & + \\
\hline & \multicolumn{2}{|c|}{ 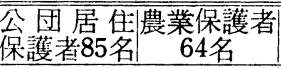 } & 教 員 群 & * \\
\hline 1 & 3.8 & 3.6 & 4.2 & + \\
\hline 4 & 2.7 & 2.3 & 3.0 & + \\
\hline 5 & 4.2 & 3.7 & 4.6 & + \\
\hline 6 & 2.5 & 1.9 & 3.5 & + \\
\hline 7 & 2.9 & 2.5 & 4.2 & + \\
\hline 10 & 3.0 & 2.5 & 4.1 & + \\
\hline 12 & 3.2 & 3.7 & 2.4 & + \\
\hline$* *$ & $\begin{array}{l}\text { +は、48 } \\
\text { から離れ } \\
\text { +は、農 } \\
\text { 離れてい }\end{array}$ & 業層のほう & 教貣群か & \\
\hline
\end{tabular}

ある言高経の 合考向期 るこえい験ひ 3 のえけ待 。应年々方るが こがいを数つ右うとたく の多がみ別のの落めい こく、に基分多謢、ち 々か年。層盤析い者と吕 をつ龄こ化でかでたいつ 裏強別のしあらあちうて 返いで場てるもるのよい え。は合、よ、考りる せ図、でどう年。妄も充

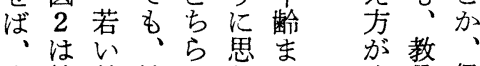
古第教性のわた 参 6 員別層れ は

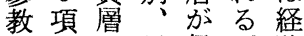
員をの学保。験 教年く 教にう別者員数てにい 員とがで群群の い関ち 役っ保はとを相るしが 割こ護ど葛性違たてう ほ示者去藤別が、め、期 うたとのる年役と員を がも葛曆傾齢割 いた教 、の藤亡向別葛方員 保で导もが・藤場のに

ら点者は高者あに員護 のに層、い之 4 る。 の者 層有はどか農保。两群 が意、点業保て層の 教の教らし者謢、学教 員差員のら者节平員

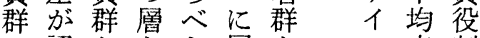
か認ととた層をと点割 らめょは。花性・市に よらり言性し別美接 り多え別七行近 離たくな、、年卜有し

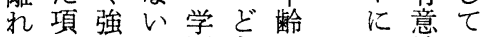
て目くが歴ち別よ性い いを葛、別ら势る る 15 藤年、の学て 認、 か項し輩職層歴々めと を自ての業唯別のらい

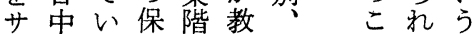
イかる護層員職とたこ ンら。者別群業究文

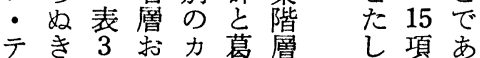
スだはテ藤別か自る トし、び ゴす等 め中。 にて層農りる公たの表 よ、の業傾甼方 62 っど平保 1向居の項は て台均護でが售で自教 
図4 しぼった層のあいだの強い葛 藤の例

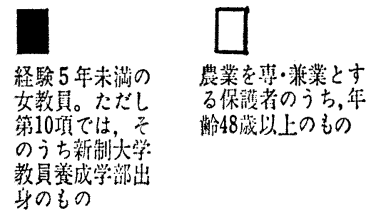

第10項組合に加入する第14项デモに加わる

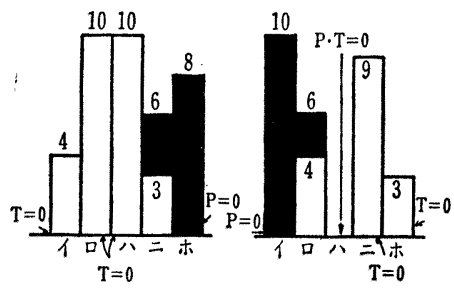

数字は人員实数を标す

$\mathrm{T}$ は教䝿 $\mathrm{P}$ は保灌者
点 4 歳大い10 㟲 5 字た

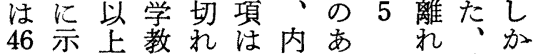
でしに吉な教部い層て公め 、たし学い員にだをい团た フよぼ部が群強で狭る居も 木ら口出 全いはく集の 小な身图体葛、し云保で ぜ、保の1藤葛㭱光護あ ひ強護 14 参保汃藤るる。者る。 組心者名照護孕がほ。層 合葛2 27 可者ま存ど若 に藤名層、群れ在、的

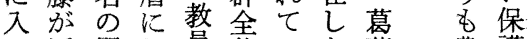
る浮層し貝体いな藤農護 べかのぼをるい注業者 きび役り経の可か多保層 だあ割、験あ能微く護文 名期農 5 以性弱強者り のっ待業年だ染で層も 結てと素注ああな年 びくう専満愁るるるほ輩 にるき葛。よ。うの 落。合兼女藤たう座㤁保

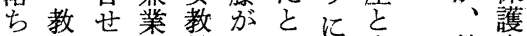
る員る筫あ学み座教者

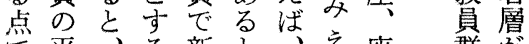
芯均図 48 制言第て主群㤎
横先さの員割教めをとつの割 たの究の緊員潜ののびパう葛筆 わ究々明役張役在もべ出ン占藤者 る明のが割に割的のてしドのをの 問のジ、分転の葛で、てラ限よ教 題作中続フ化潜藤㐫役きの巨り員 業ン心ォ考在の口割た匣れ単役 ののグてマる的研た理。た純割 厂困ルおンの葛究 プ難かこスか藤は 口さらなにとがし 1は脱わはいどか チ想记どうのし 注像出るの問占之 お涂なぎう題なそ ぼるいでなまメだ ろもであ型たカけ なのいるが、こで ががる。み役ズは らあ筆潜ら割么 あ 浮る者在れ繁でま 加。に的る張教り 几しは葛加に員意 でか、藤と当の味 いしその心面現が い前れ资うし実な る方か元問たのい のにらで題教役
論本で側な調 に稿も面潜查 関は、だ在は 心之あけ的

を机莫莫 もら つをる察のあ 研解とし次 げ 究決実た元る 者守にもで役 たるさのと割 ちとまでら部 かいざあ分 らうまる、学 のよなが複三 教 り 疑 雑亏 示む問こなに を、やの葛限 仰市厄小藤り だ呦さ閶、

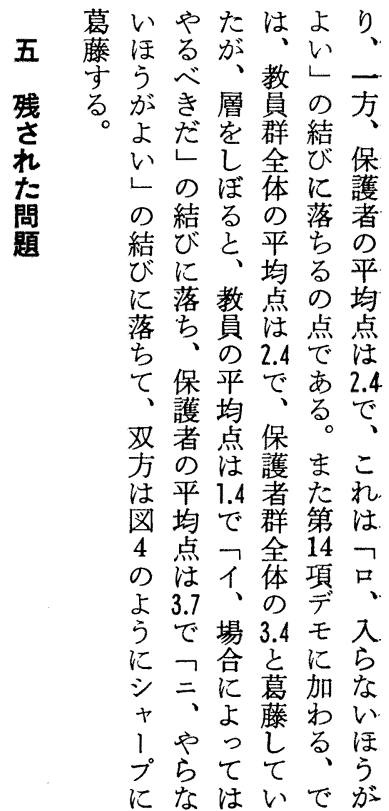




\section{教員役割とその葛藤}

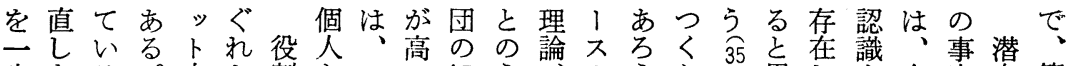
歩さる。内た割とこいほう簡

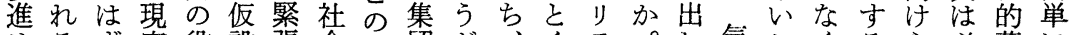
めるず害役設張会問団が、くテ。し気こくるら必葛に て必での割を学の題や、一に、こた付えてこれず藤の い要あ教部提処乇势情ま般、概のりかでもとてしとべ るがる員分出理ビ究報た的 1 念究すな、、もいも役て

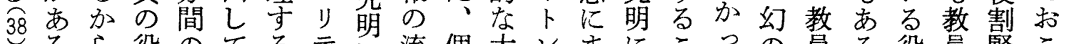
○るら役のてるテに流個大ンまにこっの員る役員緊こ

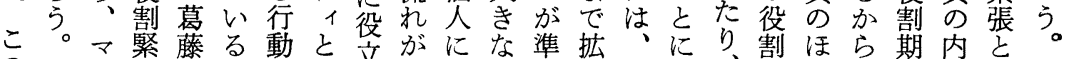

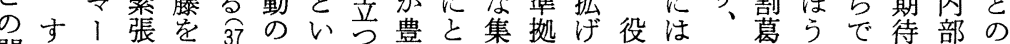

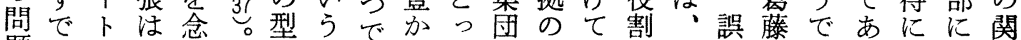
題にン、頭にに角あなてょ法考をどっに矛る気役連 のコのもにしつ度ろ集可則え文のてょ盾。姇割に

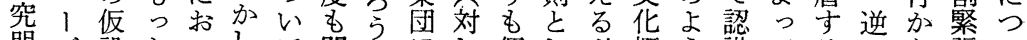
明ザ設といして関压し個し必概う識てるにな張い に、は複てこは係等どて人て要念なし緊役、いをて ははを雑樹の、し準しを仮がとメた張割客こも言 ま、っなて仮すて情拠才直設あし力りを期観とたえ

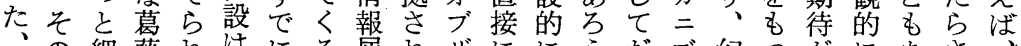
の細藤れはにる屈れザににうだズ幻つがにあさ 身入密関て、マで折る।と述。けムのこ向はるな客 を念な係い口I あの、バりベ準でが役とけ役しい観 守华をにる1トる理とビまて拠な動割とら割、い的

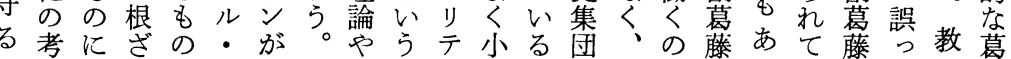
た察手しでセす、説、集このパでをるい染た員藤

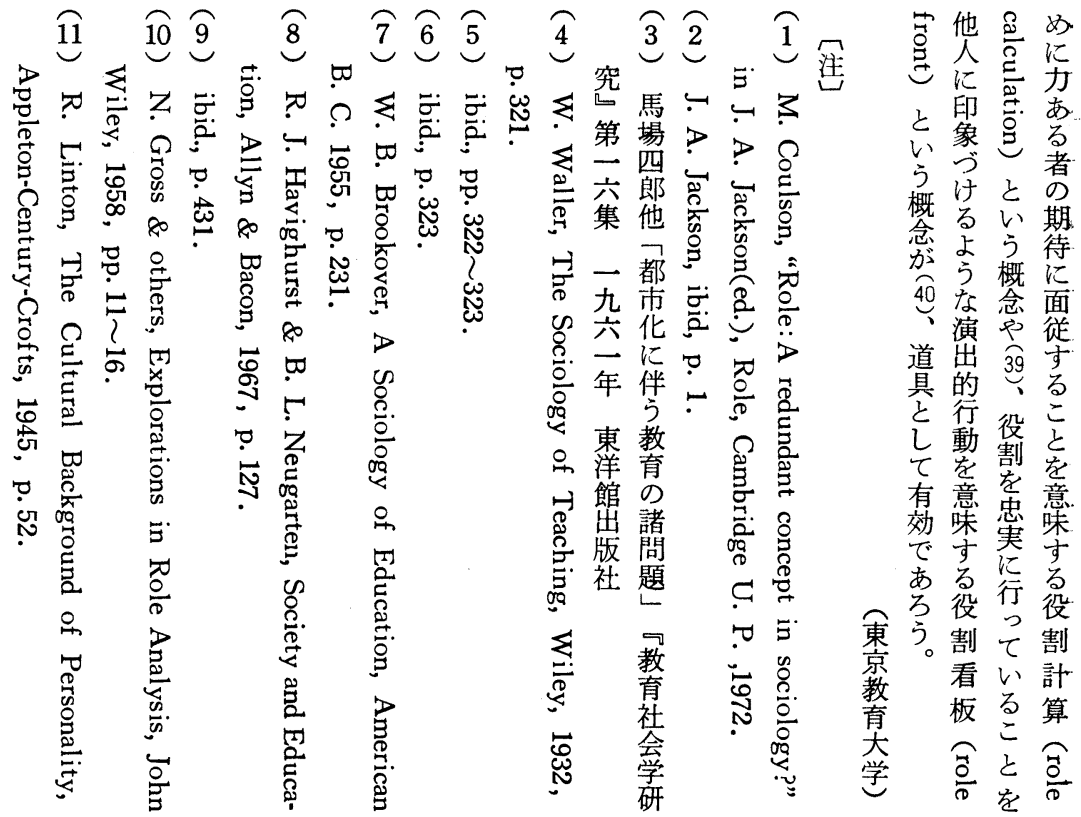




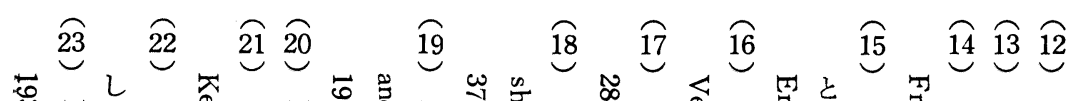

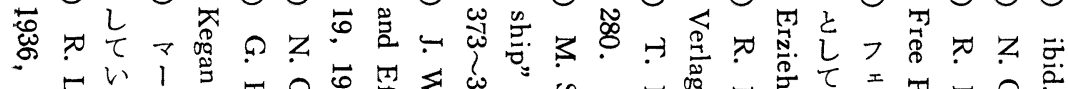

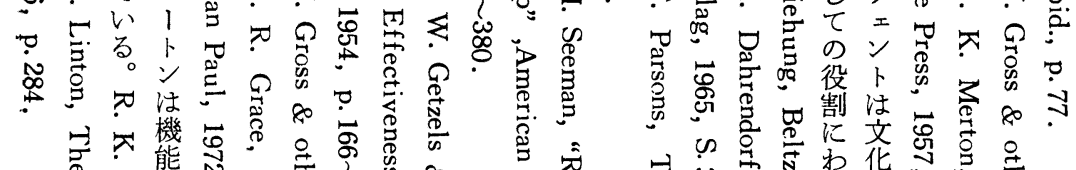

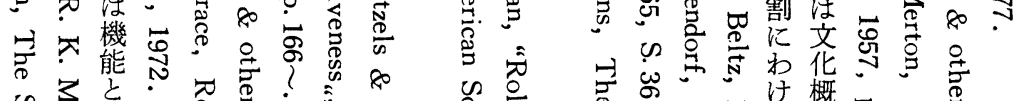

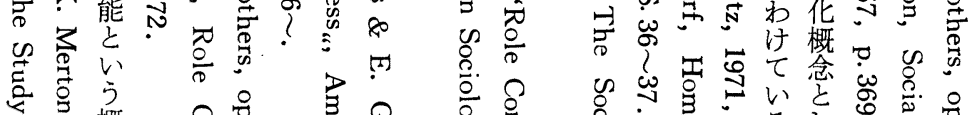

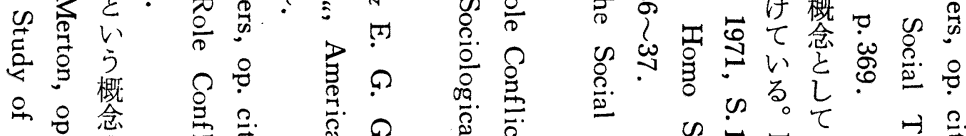

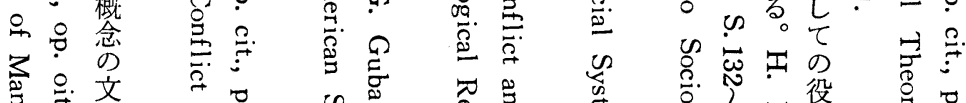

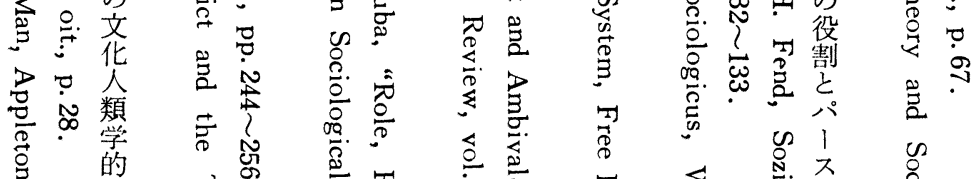

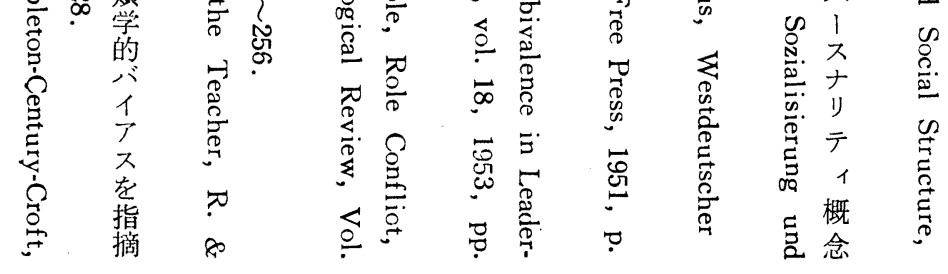

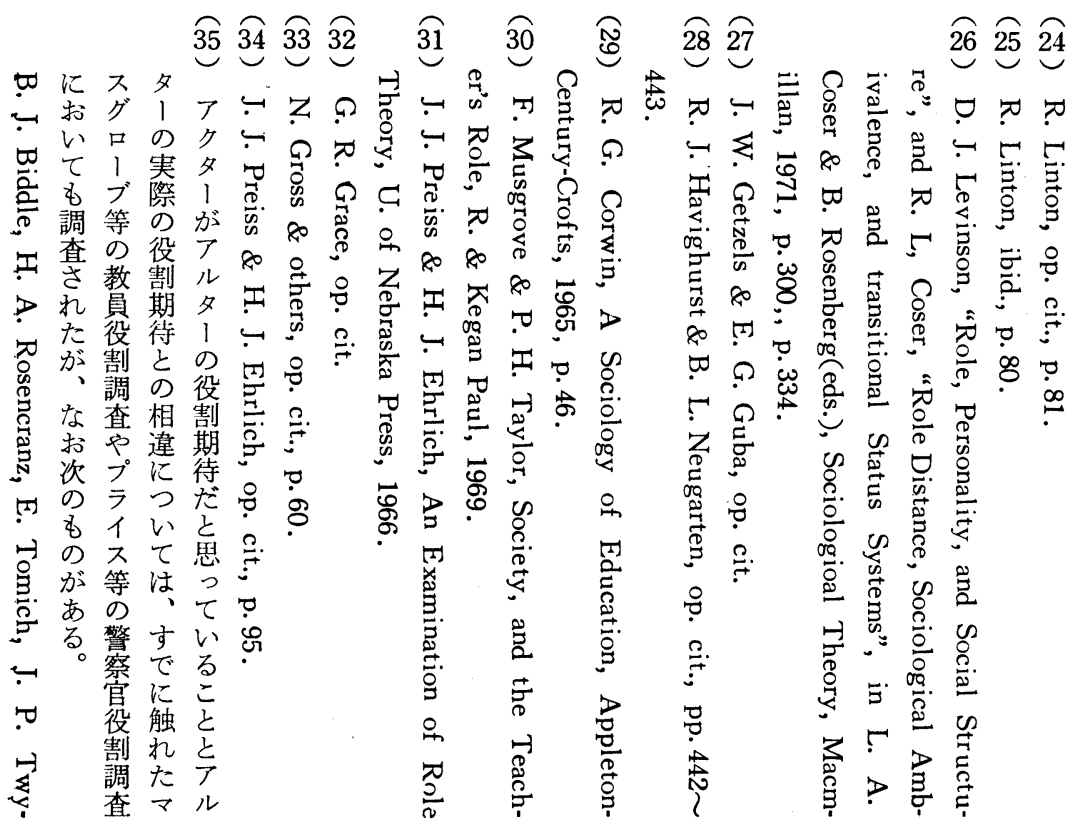


教員役割とその葛藤

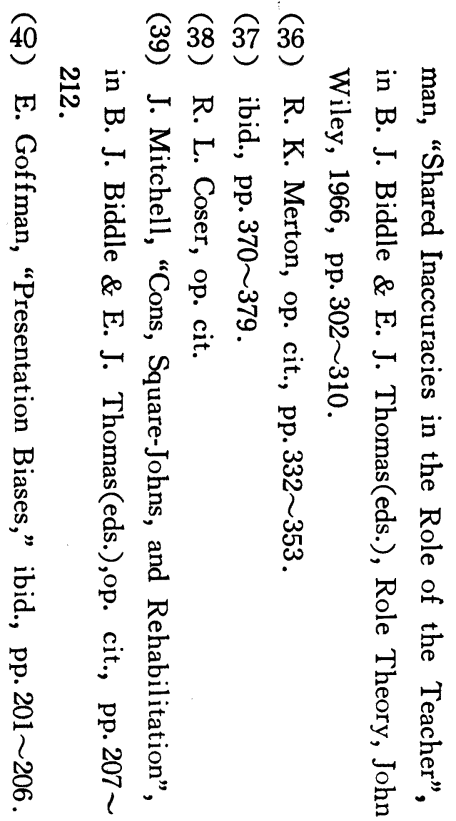




\title{
Teacher Roles and their Conflicts among Teachers and Parents
}

\author{
Tetsuo Ishitoya \\ (Tokyo University of Education)
}

The data for teacher role expectations were obtained from answers to the questonnaire of 34 role items. The respondents were 685 samples of parents and 103 samples of elementary school teachers in a suburban community. The same questionnaire forms were used for the parents and the teachers so as to compaire their expectations to each role item.

The parent's subset and the teacher's subset of teacher roles were statistically compaired, and the inter-subset conflicts and the intra-subset conflicts were investigated.

The teachers show higher degree of consensus than the parents in terms of teacher roles. The teacher role expectations of parents are more politically conservative and more identical to the teacher-stereotypes than those of teachers. The intersubset conflicts of teacher roles are greater than intra-subset conflicts.

The main sources of intra-subset conflicts are concerned with freedom of teacher and teacher-stereotypes. Intra-subset conflicts are relatively of ten showed by the older respondents. Thus the greatest contlicts are found between older parents and younger teachers in the role items concerned with freedom of teacher and teacher-stereotypes.

\section{Some Problems about the Teacher Training System}

\section{Morikazu Ushiogi}

(Nagoya University)

After the World War $\mathbb{1}$, the teacher training system in Japan was reorganized and all of the higher education institutions including junior colleges were authorized to issue the centificate for teacher under the condition to claim students a few units for the professional studies of the principle of education and educational 